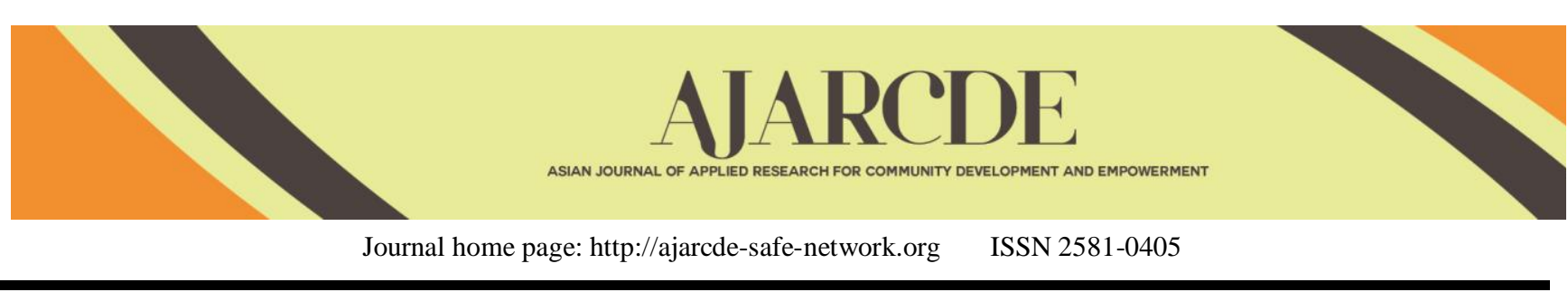

\title{
Analysis and Development of Cocoa Agribusiness in Kare Village, Madiun District, East Java
}

\author{
Nisa Hafiidhoh Fitriana, Indra Tjahaja Amir and Pawana Nur Indah \\ Department of Agriculture, Faculty of Agriculture, University of Pembangunan National Veteran East Java, Surabaya city,Indonesia \\ Corresponding author: pawana_ni@upnjatim.ac.id
}

\begin{tabular}{l} 
ARTICLE INFO \\
\hline Article History: \\
Received: 02 June 2020 \\
Final Revision: 13 July 2020 \\
Accepted: 17 July 2020 \\
Online Publication: 30 August 2020 \\
KEYWORDS \\
\hline
\end{tabular}

financial feasibility, chain and marketing margins, direction of agribusiness development, Cocoa

\section{CORRESPONDING AUTHOR}

*E-mail: pawana_ni@upnjatim.ac.id

\section{A $\quad$ B $\quad \mathbf{S} \quad \mathbf{T} \quad \mathbf{R}$ A $\mathbf{C}$ T}

Cocoa is one of the plantation commodities whose role is quite important for the national economy, especially as a provider of employment, a source of income, and foreign exchange. Financial profit is a necessity in exploiting a commodity. The market aspect is one of the determining factors for the success of cocoa plantation operations. So the results of the analysis above are combined with stakeholder opinions on the development of cocoa agribusiness. The objectives of this study are: 1) Analyzing the financial feasibility of cocoa farming 2) Analyzing cocoa farming chain and marketing margins 3) Identifying stakeholders' opinions on alternative decision making for cocoa agribusiness development 4) Developing cocoa agribusiness development directives. Financial feasibility analysis methods (NPV, Net B / C, IRR, Payback Period, and Sensitivity Analysis), marketing analysis (chain analysis and marketing margins), and Analytical Hierarchy Process (AHP). The results showed that: (1) Cocoa farming is feasible to be developed financially, because the value of NPV > 0, Gross B / C > 1, Net B / C > 1, IRR > applicable interest rate, and return on capital with a time limit less than 20 years. The sensitivity of cocoa farming occurs in decreasing production. Where cocoa farming is still feasible if these conditions occur. (2) Marketing chains and margins, namely, there are two cocoa marketing channels, marketing margins of IDR 5,000 and IDR 2,000. (3) The selection of alternatives that greatly affect the development of cocoa agribusiness is market factors, HR factors, and technology factors. The direction of agribusiness development needed is the availability of a market that has stable cocoa prices for farmers, the availability of skilled human resources in cultivation and post-harvest technology that is able to provide greater added value to cocoa.

\section{INTRODUCTION}

\subsection{Research Background}

The Agriculture sector is the main base of the nation's economy in Indonesia. As an agrarian country, the agricultural sector is an important aspect of food defense and sovereignty. Plantation subsector which is part of the agricultural sector plays an important role for national development. Sub-sectors in plantations increase farmers' incomes, open up broad employment opportunities, increase exports and create regional economic growth 1]. Cocoa is one of the plantation commodities whose role is quite important https://doi.org/10.29165/ajarcde.v4i2.45 for the national economy, especially as a provider of employment, a source of income and the country's foreign exchange. In 2017, the area of cocoa plantations according to the status of concessions in Indonesia reached 1,658,421 ha with a production of 590,684 tons, in 2018, the area of cocoa plantations according to the status of concessions in Indonesia reached 1,678,268 ha with a production of 593,833 tons, in 2017 , plantation area according to the status of cocoa in Indonesia reached 1,683,868 ha, with a production of 596,477 tons [2].

The quality of exported cocoa is generally not good, because it is not fermented. About 90 percent of cocoa exports are random or unfermented cocoa, unfermented cocoa indeed has a market in 
the world. The imposition of an export tax on Indonesian cocoa beans significantly affects the increase in the volume of Indonesia's processed cocoa exports in the long run [3]. Shortterm and long-term relationships, international prices have a significant effect on domestic prices, there is a strong correlation between export taxes and farmer prices as international prices are well transmitted to domestic prices [4]. The demand for cocoa as an industrial raw material continues to increase, both in the domestic and foreign markets. Currently cocoa farming does not appear to be a priority crop (being a side farm) in the perspective of the interests of household income [5]. This causes the price of the cocoa commodity to be quite high and tends to be stable. Considering its role and potential, cocoa is a promising plantation commodity to be developed in supporting regional development in Madiun Regency, for cocoa agribusiness development a direct approach is needed.

Madiun District is the third largest cocoa producer in East Java with a total plantation area of 5,843 ha in 2017 with a production of 3,145 tons[6]. In terms of productivity, the highest productivity of cocoa compared to East Java, which is Banyuwangi 7,760 tons / ha, followed by Kediri City and Madiun Regency respectively 3,151 tons / ha and 3,145 tons / ha. This is one area in East Java that has very good potential for cocoa development. A well-managed cocoa plantation business starts from cultivation, postharvest, processing industry, to distribution and marketing processes with effective institutional support can improve the welfare of farmers and stakeholders.

For this reason, it is necessary to develop cocoa plantations for the community in choosing the right one so that the results and benefits that are maximized therefore with a large potential to increase cocoa production must be developed. Sustainable institutions were not fulfilled and concluded that important structural changes in the cocoa sector were needed to achieve this goal, these changes involved the financial viability of cocoa in small farms, marketing chains and margins at the village level and the determination of cocoa agribusiness development. Implementation of this change requires an area-specific program with their common goal of increasing economically and environmentally sustainable cocoa production on less land [7].

The problem is, is the marketing chain for cocoa commodities in Madiun Regency currently efficient? Efficient in the sense that the benefits derived by farmers are proportional to the capital they incurred, and do prices at the farm level have a high degree of integration with prices at the district trader level? If it is not efficient, what factors cause and what are the alternative solutions to the problem so that the cocoa commodity marketing chain in Madiun Regency becomes more efficient. On the other hand reducing the risks faced by farmers, there needs to be government intervention, especially in creating policies and regulatory frameworks that are targeted at the cocoa sector. In addition, the government must put in place marketing schemes and targeted pricing regulations to help cocoa farmers [8].

The results of the above analysis need to be integrated with stakeholders' opinions on the development of cocoa plantations, so that it can be used as a guideline or alternative selection in developing cocoa plantations in Madiun District. The existence of an alternative selection in the development of cocoa plantations is expected to increase the income and welfare of cocoa farmers while supporting the improvement of the regional economy in accordance with the concept of sustainable development that is in accordance with environmental, economic and social aspects.

\subsection{Literature Review}

\subsubsection{Cacao}

Theobroma cacao is the biological name given to the cacao tree by Linnaeus in 1753. The natural place of the genus Theobroma is in a part of tropical forest with a lot of rainfall, high humidity, and shade. In this condition, Theobroma cocoa rarely produces fruit and only produces a few seeds. The cocoa plant consists of 2 (two) types which are distinguished by the color of the seeds, the white color of the Criollo group, while the seeds of the puIDRle plant belong to the Forastero group. Cocoa beans are needed in various industries because of their unique characteristics, namely: (1) cocoa beans contain quite high fat $(55 \%)$, where fat has unique characteristics that are frozen at room temperature but melt at body temperature, (2) the solid part of Cocoa beans contain flavor and coloring components that are needed in the food industry.

\subsubsection{Financial Feasibility Analysis of Cocoa}

Financial analysis is the activity of evaluating and determining the rupiah unit of aspects that are considered feasible from decisions made in the stage of business analysis[9]. There are several financial feasibility analysis tools namely NPV, Net B / C, IRR, Payback Period and sensitivity analysis

\subsubsection{Chain and Margin Marketing}

A marketing channel is a group of traders and coIDRorate agents that combine physical demand and the rights of a product to create uses for a particular market [10].

\subsubsection{Agribusiness Development}

Agribusiness development is an activity related to the handling of agricultural commodities in a broad sense, which includes one or all of the production chains, processing input and output (agroindustry), marketing input - output agricultural output and institutional support for agricultural activities, which is meant by relating is business activities that support agricultural activities and business activities supported by agricultural activities. Agribusiness development aims to make modern or reliable farmers who can manage their agricultural commodities from preharvest to post-harvest or marketing [11].

\subsection{Research Objective}

The objectives of this study are as follows: 1) Analyzing the financial feasibility of cocoa farming 2) Analyzing the marketing and marketing margins of cocoa farming 3) Identifying stakeholders' opinions on decision making for alternative cocoa agribusiness development 4) Developing directions for cocoa agribusiness development.

\section{MATERIALS AND METHODS}

\subsection{Data Types and Sources}

The data used are primary and secondary data. Secondary data obtained from literature, books, cocoa statistics central body, journals, previous research as well as from various books such as cocoa theory, financial feasibility theory of cocoa production, chain theory and marketing margins, theory of cocoa plantation development company data related to production data, cocoa 
product sales. Whereas primary data were obtained through several methods, namely structured observation and interviews.

\subsection{Sampling Method}

Sampling is purposive sampling. The considerations used to determine the sample are farmers who have the main outpouring of work, the trading agency as well as information and knowledge from stakeholders. The total sample used was 54 people with determined considerations.

\subsection{Analytical methods}

To evaluate the feasibility of community cocoa plantations in each the level of land suitability in Madiun Regency, the analysis was carried out financial feasibility. To find out the level of financial feasibility, it can be used some criteria (analytical tools). NPV calculation in an investment appraisal is a practical way to find out whether cocoa cultivation is profitable or not. NPV is the difference between the present value of the benefit stream minus the present value of cost flow [13]. A cocoa plantation business activities providing benefits is an activity that gives a positive value or NPV $>0$, meaning that the benefits received by the project are greater than all the total costs issued. If NPV $=0$, the benefits obtained are only sufficient for cover the total costs incurred (BEP or TC $=\mathrm{TB})$. NPV value $<0$, means that the exploitation of the cocoa farm will suffer losses, the total cost of which issued is greater than the benefits obtained.

$$
N P V=\sum_{t=0 / 1}^{n} \frac{B t-C t}{(1+i) t}
$$

Information:

$$
\begin{array}{ll}
\text { Bt } & \text { : benefit in the t-year } \\
\text { CT } & \text { : costs in the t-year } \\
\text { Q } & : \text { the duration of investment } \\
\text { I } & \text { : interest rates }
\end{array}
$$

Net Benefit Cost Ratio is a comparison between the value of benefits and the costs calculated at this time [13]. A cocoa plantation business is feasible and efficient to carry out if the Net BCR value> 1, which means the benefits obtained are greater than the costs incurred and vice versa if the Net $\mathrm{BCR}$ value $<1$, which means the benefits obtained are smaller than the costs incurred. Net $\mathrm{BCR}$ value $=1$ (one) means cash in flow = cash out flows $(\mathrm{BEP})$ or $\mathrm{TR}=\mathrm{TC}$.

$$
\text { NET BCR }=\frac{\sum_{t=0 / 1}^{n} \frac{B t-C t}{(1+i) t}}{\sum_{t=0 / 1}^{n} \frac{B t-C t}{(1+i) t}}
$$

Information:

$$
\begin{array}{ll}
\mathrm{Bt} & : \text { benefit in the } \mathrm{t} \text {-year } \\
\mathrm{Ct} & : \text { costs in the } \mathrm{t} \text {-year } \\
\mathrm{i} & : \text { interest rates } \\
\mathrm{n} & \text { : the age of the farming project }
\end{array}
$$

Internal Rate of Return (IRR) to find out the extent to which cocoa cultivation is profitable, IRR analysis is used. IRR is expressed as a percent $(\%)$ which is a measure of the success of cocoa plantation operations [13]. Internal Rate of Return (IRR) is an interest rate that shows the net present value (NPV) equal to the total investment of the project or in other words the interest rate that produces NPV $=0$.

$$
I R R=i 1+\frac{N P V 1}{N P V 1-N P V 2} x(i 2-i 1)
$$

Information:

NPV1 : Positive present value

NPV2 : Positive present value

i1 : the discount rate that generates NPV1

i2 : the discount rate that generates NPV2

Business feasibility is determined by considering the three analytical tools, where the business is feasible if the IRR value> interest rates, the project is feasible. If the IRR value <interest rate, the project is not feasible. If the IRR value = interest rate, then the Break Event project. Payback Period is the investment appraisal of a project based on the payment of investment costs based on the net benefits of a project. In this study, it will also be calculated how fast the project time is needed to return the investment and working capital invested.

$$
\begin{aligned}
\text { Payback period }= & T p-1 \\
& +\frac{\sum_{i=1}^{n} T C i c p-1-\sum_{i=1}^{n} \text { Bicp }-1}{B p}
\end{aligned}
$$

Information:

T p-1 : number of years when the cumulative Net Benefit value (negative)

TCicp-1 : total cost when the cumulative net benefit value (negative)

Bicp-1 : total amount of benefit at the time of cumulative Net Benefit value (negative)

BP : number of benefits in the initial year Net Benefit value (positive)

Eligibility criteria if the payback period is shorter than the economic life of the business, the project is feasible to be developed and if the payback period is longer than the economic life of the business, the project is not feasible to be developed the risk analysis.

Sensitivity analysis (sensitivity analysis) is carried out to reexamine a feasibility analysis of cocoa plantation exploitation, in order to know the effect that will occur due to changing circumstances or there is an error in the basis of calculating costs and benefits. Sensitivity analysis (sensitivity) is an analytical technique that systematically tests what happens to the capacity of receiving a business activity if events occur that are different from the estimates made in the planning.

Analysis of the cocoa marketing chain is carried out by tracing existing marketing activities ranging from farmers to large traders. Marketing margins are used to find out where the biggest profit from the marketing chain of cocoa beans is in Kare village, Kare sub-district, Madiun district. The greater the share of prices received by farmers, it means that farmers' bargaining position is more profitable, and vice versa.

Data analysis on alternative decision making for the development of cocoa plantations using AHP. AHP is an analysis used in decision making with systems and helps in making predictions and decision making. The basic principles of AHP work are outlined as follows:

1. Arrangement of Hierarchy

2. Rating criteria

3. Determination of priorities

4. Logical consistency 
The criteria are assessed through pairwise comparisons, that is, comparing each element with other elements at each level of interest of elements in a qualitative study.

Table 1. Analytical Hierarchy Process (AHP) Basic Ranking Scale

\begin{tabular}{ll}
\hline Value & Information \\
\hline $\mathbf{1}$ & Both elements are equally important \\
\hline $\mathbf{3}$ & $\begin{array}{l}\text { One element is slightly more important than the } \\
\text { other elements }\end{array}$ \\
\hline $\mathbf{7}$ & $\begin{array}{l}\text { One element is more important than the other } \\
\text { elements }\end{array}$ \\
& $\begin{array}{l}\text { One element is clearly more important than the } \\
\text { other elements }\end{array}$ \\
\hline $\mathbf{9}$ & $\begin{array}{l}\text { One element is absolutely more important than the } \\
\text { other elements }\end{array}$ \\
\hline $\mathbf{2 , 4 , 6 , 8}$ & $\begin{array}{l}\text { The values between the two considerations are } \\
\text { close together }\end{array}$ \\
\hline $\mathbf{S 0}$
\end{tabular}

Source: [14]

\section{RESULT AND DISCUSSION}

\subsection{Financial Feasibility Analysis of Cocoa Farming}

Financial feasibility analysis of Kare village cocoa farming includes calculation of Net Present Value (NPV), Net Benefit Cost Ratio (Net BCR) and Internal Rate of Return (IRR) which reflects the level of financial feasibility of cocoa farming in kare village after being corrected with an interest rate of $6 \%$ (Discount Rate). This analysis is carried out in the assumption used is the productive age of cocoa plants for 20 years, cocoa plants begin to produce at the age of 3 years, the pattern of price assumptions used in this analysis is a constant price of IDR. 27,000 per kilogram, the price prevailing at the farm level when collecting data in the field (February 2020). The prevailing interest rate is assumed to be $6 \%$. Labor is calculated using daily wages that are converted into working day (HOK) and labor wages during the observation period, which is IDR. 80,000 / day. Calculation of production costs, investment costs, and the amount of production based on the results of research on cocoa plants aged 1 year to 20 years. Financial analysis calculations are carried out for an area of 1 hectare. The sample of farmers taken is representative of each farmer group that is suitable for the development of cocoa plants that have high productivity. Besides that, farmers were also chosen, the majority of which residents working on cocoa plantations. The results of financial analysis are used to determine the comparison between the amount of costs incurred with the revenue from a production process, whether the production process is feasible to be worked on and can provide benefits. Calculation of financial analysis of cocoa farming in Kare Village, Kare Subdistrict, Madiun Regency can be seen in Table 2, while the details of financial analysis calculations can be seen in the appendix. This financial analysis calculation is based on the average input and output structure data of each farmer, which consists of twenty sample respondents.
Table 2. Financial Analysis (NPV, Net B / C Ratio, IRR and Payback Period) Cocoa Fermentation in 1 ha at an interest rate of $6 \%$ in Kare Village Kare Subdistrict Madiun Regency

\begin{tabular}{|l|l|}
\hline Criteria & Value \\
\hline Net Present Value (IDR) & 73.637 .133 \\
\hline Net B/C & 9.8 \\
\hline IRR $(\%)$ & $32.79 \%$ \\
\hline Payback Period (years) & 7 years \\
\hline
\end{tabular}

Based on Table 2 the results of the NPV analysis show that the difference between the present value of the receipts received and the present value of the costs incurred for cocoa farming has a positive value of IDR 73,637,133. This means that the present value of revenue in the future is still greater than the present value of costs incurred in the future.

Table 2 shows the results of the calculation of Net B / C at an interest rate of $6 \%$ of 9.8 , which means that cocoa farming in Kare Village, Kare Sub-district, Madiun Regency is feasible and efficient to be continued and developed because the Net B / C value> 1 . Table 2 shows the amount of IRR at an interest rate of $6 \%$ for cocoa farming is $32.79 \%$, which means the IRR value is greater than the prevailing interest rate. This shows that cocoa farming in Kare Village, Kare Sub-district, Madiun Regency is profitable and feasible to be developed.

$$
\begin{aligned}
& I R R=i_{1}+\frac{N P V_{1}}{N P V_{1}-N P V_{2}} \times\left(i_{2}-i_{1}\right) \\
& I R R=0,06+\frac{73.637 .133}{73.637 .133-(-15.567)} \times(0,328-0,06) \\
& I R R=0,3279 \\
& I R R=32,79 \%
\end{aligned}
$$

This value means that cocoa farming will provide a return to the invested capital of $32.79 \%$ during the economic life of the plant. From the information in table 2 it can be seen that the number of years when the NBK is negative is 7 years, then the following payback period will be calculated:

$$
\begin{aligned}
& \text { Payback Period }=T_{p-1}+\frac{\sum T C_{i c p-1}-\sum B_{i c p-1}}{B P} \\
& \text { Payback Period }=7+\frac{18.222 .500-17.793 .000}{10.719 .000} \\
& \text { Payback Period }=7.04 \approx 7 \text { years. }
\end{aligned}
$$

Thus the fastest time needed by the project to return the initial investment and working capital is 7 years, so that the return on investment capital is shorter than the economic life of the project which is 15 years. In this study sensitivity analysis was also carried out. According to Ref. [15] sensitivity analysis is carried out to re-examine the feasibility of a business activity, in order to know the effect that will occur due to changing circumstances or there are errors in calculating costs and benefits. 
Table 3. Financial Feasibility Analysis (NPV, Net B / C Ratio and IRR) Cocoa Plantation in 1 ha in Kare Village, Kare Subdistrict, Madiun Regency with a production reduction scenario.

\begin{tabular}{llll} 
No & Parameter & \multicolumn{2}{c}{ The situation } \\
\cline { 3 - 4 } & & Normal & $\begin{array}{l}\text { Production } \\
\text { decline 16\% }\end{array}$ \\
\hline $\mathbf{1}$ & $\begin{array}{l}\text { Net Present Value } \\
\text { (NPV) }\end{array}$ & $73,637,133$ & $55,991,297$ \\
\hline $\mathbf{2}$ & Net BCR & 9.8 & 7.5 \\
\hline $\mathbf{3}$ & $\begin{array}{l}\text { Internal Rate of } \\
\text { Return (IRR) }\end{array}$ & $32.79 \%$ & $28.9 \%$ \\
\hline $\mathbf{4}$ & Payback Period & 7 years & 7.4 years \\
\hline
\end{tabular}

Source: Processed Data, 2020

Based on Table 3 it can be seen that the decrease in production amount by $16 \%$ with fixed input costs resulting in a decrease in the value of NPV, Net BCR, and IRR but even so the criteria index is still in the assessment or decision is feasible and business activities can be continued. When production conditions declined by $16 \%$, the cocoa plantation project was still feasible to be carried out with a payback period of 7.4 years, despite a significant decrease in net present value.

\subsection{Chain and Margins Marketing}

Analysis of the cocoa commodity chain and marketing margins in this study only analyzed limited marketing institutions for fermented cocoa beans in Kare Village, Kare Subdistrict, Madiun Regency. Two forms of cocoa commodity marketing chains in Kare Village, Kare Sub-district, Madiun Regency are presented in Figure 1.

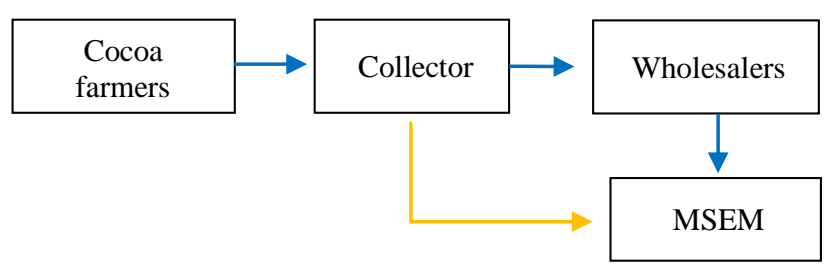

Fig. 1. Cocoa Supply Chain in the village of Kare, Madiun

Marketing Chain I is village collectors buy from farmers, village collectors sell to big traders, wholesalers sell to Agroindustry. Marketing Chain II is farmers sell directly to large traders, large traders sell to MSMEs.

In Table 4 for marketing chain II, it can be seen that farmers sell their crops to large traders at an average price of IDR. 28,000 $/ \mathrm{kg}$. Large traders sell cocoa to MSMEs with an average price of IDR $30,000 / \mathrm{kg}$, marketing margin obtained is IDR 2,000/ kg while marketing costs are IDR $250 / \mathrm{kg}$. The profit margin ratio (IDRM) obtained by large traders is 0.875 . This means that every IDR 100, issued by a large trader, will give a profit of IDR 875 .
Table 4 Analysis of Marketing Margins of Cocoa beans in Kare

\begin{tabular}{|c|c|c|c|}
\hline \multicolumn{4}{|c|}{ Marketing Chain I } \\
\hline No & Description & Unit & Value \\
\hline \multirow[t]{3}{*}{1} & Farmers & & \\
\hline & Total Cost & IDR / Kg & 900,00 \\
\hline & Selling Price & IDR / Kg & $27,000.00$ \\
\hline \multirow[t]{4}{*}{2.} & Village trader & & \\
\hline & Total Cost & IDR / Kg & 470.00 \\
\hline & Selling Price & IDR / Kg & $28,000.00$ \\
\hline & Marketing Margin & IDR / Kg & $1,000.00$ \\
\hline \multirow[t]{4}{*}{3.} & Wholesalers & & \\
\hline & Total Cost & $\mathrm{IDR} / \mathrm{Kg}$ & 140.00 \\
\hline & Selling Price & IDR / Kg & $32,000.00$ \\
\hline & Marketing Margin & IDR / Kg & $4,000.00$ \\
\hline \multicolumn{2}{|c|}{ Total Margin } & IDR / Kg & $5,000.00$ \\
\hline \multicolumn{4}{|c|}{ Marketing Chain II } \\
\hline \multirow[t]{3}{*}{1} & Farmers & & \\
\hline & Total Cost & IDR / Kg & 660,00 \\
\hline & Selling Price & IDR / Kg & $27,000.00$ \\
\hline \multirow[t]{4}{*}{2.} & Village trader & & \\
\hline & Total Cost & IDR / Kg & 210.00 \\
\hline & Selling price & IDR / Kg & $30,000.00$ \\
\hline & Marketing Margin & IDR / Kg & $2,000.00$ \\
\hline \multicolumn{2}{|c|}{ Total Margin } & & $2,000.00$ \\
\hline
\end{tabular}

\subsection{Selection of Alternative Strategies}

Various alternative strategies that will be responded by experts in the Analytical Hierarchy Process (AHP) questionnaire are the results of preliminary research that summarizes the various references and selection of various opinions of stakeholders involved in policy makers as well as in cocoa cultivation. Then various alternative strategies are assessed in the form of pairwise comparisons.

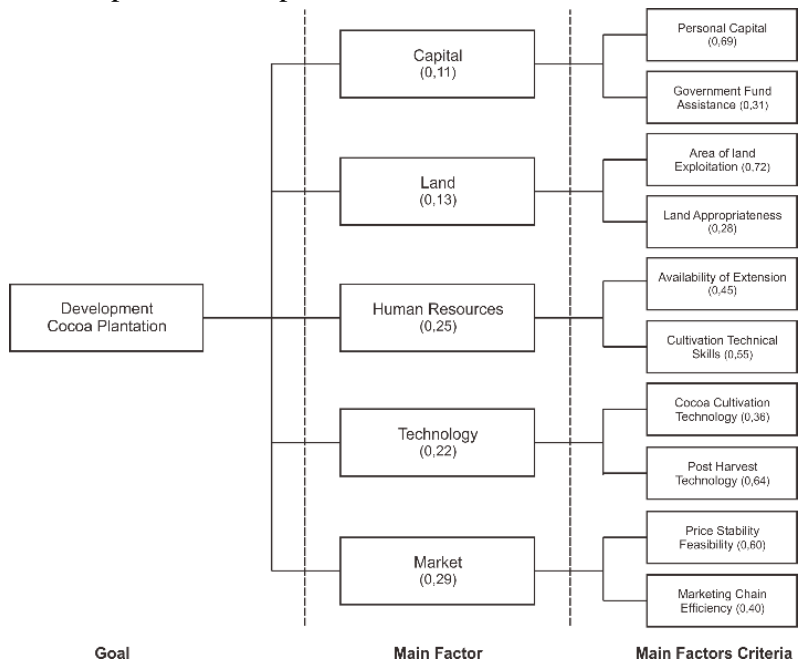

Fig. 2. Cacao Hierarchical Structure of the Main Factors and Criteria of the Main Factors

In the opinion of stakeholders, the main factors influencing the development of cocoa agribusiness along with the value of their weights sequentially with a value of consistency ratio (CR) of 0.06 are market factors (0.29), human resource factors (HR) $(0.25)$, technology factors $(0.22)$, land factor $(0.13)$ and capital factor (0.11). Based on the opinion of stakeholders, the most 
important factors to consider in developing cocoa agribusiness in the future are the market factors of the cocoa commodity, human resource factors related to cocoa cultivation and technological factors that support cocoa plantation operations. Where the factors that greatly influence the development of cocoa agribusiness in Kare Village, Kare Subdistrict, Madiun Regency are market, HR and technology factors. This is thought to be caused by different scopes of research.

\subsection{Direction of Agribusiness Development}

Based on the results described above, the priority of the strategy for developing cocoa plantations in Kare village, Kare Subdistrict, Madiun Regency is based on a combination of all sub criteria, the feasibility of price stability is the first priority. The second priority is technical cultivation skills and the third is postharvest technology. As an alternative strategy for the development of smallholder cocoa plantations is the strength that is possessed through utilizing opportunities and opportunities including resources, business management and infrastructure in community cocoa[16].

Future directions for developing cocoa plantations must pay close attention to marketing aspects of cocoa commodities, human resources (HR) and supporting technologies in cocoa cultivation and post-harvest. Marketing aspects include the availability of markets that will accommodate farmers' harvests and marketing chains of cocoa commodities and add insight into the basis of cocoa prices. According to the parties involved in the development of cocoa plantations (stakeholders), the availability of markets with reasonable and relatively stable prices will motivate farmers to operate their cocoa plantations.

In addition to marketing aspects of cocoa commodities, the availability of human resources also needs to be the focus of attention in the future development of cocoa plantations. The support of reliable human resources can greatly increase the productivity of cocoa plants, both agricultural extension human resources and the farmers' own human resources. Technological factors must also be considered in the cultivation of cocoa plantations, with the availability of this technology is very helpful for farmers in the operation of their cocoa plantations. Technology in cocoa cultivation is very much needed, such as the availability of equipment for maintaining cocoa plants and the availability of production facilities such as fertilizers and medicines. In post-harvest technology, it is also very necessary, if the farmers have the will to add value to the cocoa itself, this can employ the wives of farmers to process post-harvest.

\section{CONCLUSION}

The conclusion of this study is that the cocoa 1. Cultivation of fermented cocoa farming in Kare village, Kare sub-district Madiun Regency is feasible to be developed financially, because of its value NPV > 0 , Net B / C > 1, IRR> applicable interest rates, and return of capital with a deadline of less than 20 years. 2. There are two forms of cocoa commodity marketing chains in the Kare village Kare District Madiun Regency namely: (1) marketing chain 1: farmers - village collectors - big traders - industry; (2) marketing chain 2: farmers - big traders - MSMEs. From the two marketing chains judging by the value of marketing margins, the marketing chain 2 give the farmer a higher price share. 3. Selection of alternative strategies that greatly affect development cocoa agribusiness in the village of Kare Kare District Madiun Regency is capital factors, land factors, human resource factors, market factors and factors technology. 4. Directives for the development of cocoa plantations in the Kare village District Kadi Madiun District shows that the three priority criteria are key in cocoa agribusiness development is the availability of markets that have stability of the price of cocoa for farmers, the availability of human resources skilled in cultivation and capable post-harvest technology provide greater value added cocoa.

\section{REFERENCE}

[1] Rompas, J., D. Engka and K. Tolosang, "Potensi sektor pertanian dan pengaruhnya terhadap penyerapan tenaga kerja di Kabupaten Minahasa Selatan," Jurnal Berkala Ilmiah Efisiensi, vol. 15, no. 4, pp 124-136, 2015.

[2] Direktorat Jendral Perkebunan, "Statistik Perkebunan Indonesia 2017-2019 Kakao," Sekretariat Direktorat Jendral Perkebunan, Jakarta, 2018.

[3] Yudyanto, Hendy and Fitrah F.H., Analysis of The Imposition Of Export Tax On Indonesian Cocoa Beans: Impact On The Processed Cocoa Export Indonesia And Malaysia, Internasional Journal of Economics and Financial Issues, 2017.

[4] Nisurahmah, Andini, Nunung N., and Tanti N., Relation Analysis Of Internasional Cocoa Prices And Indonesia Cocoa Framers' Price After Export Tax Policy On Cocoa Beans, Internasional Journal of Developing and Emerging Economies, vol. 5, no. 4, pp.1-13, December 2017.

[5] Nurhadi, Eko et.al., Sustainability of Cocoa Commodities as Agro-Industry's Leading Products in Improving Farmers' Welfare, Jurnal Sosial Ekonomi dan Kebijakan Pertanian. Agriekonomika, vol. 8, no. 1, 2019.

[6] Badan Pusat Statistik. Luas Lahan dan Produksi Kakao di Jawa Timur, 2018.

[7] Wessel, Marius and P.M. Foluke Quist-Wessel, Cocoa Production in West Africa, A Review and Analysis Of Recent Developments, NJAS-Wagening Journal Of Life Sciences, pp 74-75, 2015.

[8] Babalola, Folaranmi D., et.al., Risks And Coping Strategies Associated With Production And Marketing Of Cocoa Agroforest in Ondo State, Nigeria. XIV World Forestry Congress, Durban, South Africa., pp 7-11, September 2015.

[9] Sofyan, Iban, "Studi Kelayakan Bisnis," Geraha Ilmu, Yogyakarta, 2004.

[10] Hasyim, A.I., "Tataniaga Pertanian," Diktat Kuliah Fakultas Pertanian Universitas Lampung, 2012.

[11] R. Ramadhan, S., Arida, A., \& Agussabti. (2017). Rice Agribusiness Development in Indrapuri District, Aceh Besar Regency. Agricultural Student Scientific Journal, 2 (1), 220-230. http:/jim.unsyiah.ac.id/ JFP/ article/ view/ 2274

[12] Indah. Pawana Nur, et.al., "Metode Penelitian Agribisnis," Semesta Anugerah, Surabaya, 2019.

[13] Soekartawi, "Ilmu Usahatani dan Penelitian Untuk Pengembangan Pertanian Kecil," Rajawali Press, Jakarta, 1996.

[14] Saaty TL. 1980. The Analitycal Hierarchy Process. (USA): McGraw-Hill, Inc

[15] Gitinger, J.P. 1986. Economic Analysis of Projects_Agricultural Projects.. UI Press. Jakarta

[16] Indah, Pawana Nur, et.al., Agribusiness Strategy of Cocoa Farmer's in Jember Regency, East Java, Indonesia, IOP Conf. Series: Earth and Environmental Science 347 (2019) 012116, 2019. 